\title{
Infeccions as the etiology for obesity
}

\author{
Infecções na etiologia da obesidade
}

Henrique de Lacerda Suplicy', Andressa Bornschein'

\begin{abstract}
The role of infection on obesity development has been questioned since the early 1980's. Several studies on animals have shown that fisiopathologic mechanisms through which infections can produce obesity do exist. At least eight types of obesity-inducing viruses have been identified in animals, especially poultry and mice. Studies on humans are far less convincing; however, two adenoviruses, Ad-36 and SMAM-1, have shown adipogenic properties. In vitro studies with 3T3-L1 cells stated the activation of the enzymatic pathway that leads to fatty tissue accumulation; in vivo studies have also detected higher levels of antibodies against such viruses on obese subjects. Although most known infections nowadays cause obesity through central nervous system lesions, the Ad-36 adenovirus infection affects fatty tissue directly, raising doubts regarding central role component in this case. Arq Bras Endocrinol Metab. 2009;53(2):159-164.
\end{abstract}

Keywords

Human virus infections; obesity

\section{RESUMO}

Desde o início dos anos 1980, o papel das infecções tem sido debatido quanto à etiologia da obesidade. Diversos estudos em modelos animais têm demonstrado que mecanismos fisiopatológicos ativados pelas infecções podem induzir também à obesidade. Pelo menos oito tipos de obesidade induzidas por viroses foram caracterizadas em animais, especialmente em camundongos e galinhas. Estudos em humanos existem, mas são menos convincentes. No entanto, duas adenoviroses (Ad-36 e SMAN-1) apresentam características adipogênicas. Estudos in vitro com a linhagem celular 3T3-L1 demonstraram que ativações enzimáticas levam ao acúmulo de gordura celular. Estudos in vivo detectaram níveis elevados de anticorpos contra certas viroses especialmente em indivíduos obesos. A maioria das infecções potenciais causadoras de obesidade atua produzindo ativações ou lesões no sistema nervoso central. Por outro lado, a infecção por Ad-36 adenovírus afeta diretamente o tecido adiposo, expandindo dessa forma a etiologia viral da obesidade para mecanismos hipotalâmicos e periféricos. Arq Bras Endocrinol Metab. 2009;53(2):159-164.

\author{
${ }^{1}$ Serviço de Endocrinologia \\ e Metabologia do Hospital \\ das Clínicas da Universidade \\ Federal do Paraná (HC-UFPR), \\ Curitiba, PR, Brasil
}

Correspondence to: Henrique de Lacerda Suplicy Rua Agostinho Leão Jr., 285 80030-110 - Curitiba, PR, Brasil

Received in Feb/27/2009 Accepted in Mar/02/2009

\section{INTRODUCTION}

$\mathrm{O}$ besity etiology encompasses several factors, many of which have been unquestionably related to its development: nutrition and behavioral disorders, endocrine alterations, drug use, neurologic and genetic diseases (1). The intriguing "fat epidemic", with its staggering ever-growing numbers, has been the focus of speculation regarding the true reasons for its expansion, since sedentary lifestyle and changes in diets with fat intake alone cannot fully explain it (2). An interesting observation is the similarity between the period of time in which this epidemic began and the growing number of infections to which we have been exposed. Draws attention the fact it took place in the early 1980's. Based on this finding, several studies have suggested that infections, especially viral in origin, may hold a causality relation to obesity $(3,4)$.

Infectious disease induced obesity is not a new concept on the literature (Table 1), since the first report regarding this subject was published by Lyons in 1982 (5). Surprisingly, this matter drew little attention over the past two decades and has only recently resurfaced as a subject of interest. 


\begin{tabular}{ll}
\hline \multicolumn{2}{l}{ Table 1. Human and animal obesity related viruses } \\
\hline Vírus & Year of report \\
\hline Animal & \\
\hline \multicolumn{1}{l}{ Canine distemper virus } & 1982 \\
Rous-associated virus type 7 & 1983 \\
Borna disease virus & 1983 \\
Scrapie agent & 1987 \\
SMAM-1 aviary adenovirus & 1990 \\
\hline Human & \\
\hline Adenovirus 36 & 2000 \\
Adenovirus 37 & 2002 \\
Adenovirus 5 & 2005 \\
\hline
\end{tabular}

Adapted from Vangipuram and cols. (10).

On animals, at least eight viruses and one prion have shown causal relation to obesity in several studies $(6,7,8)$. Other two adenoviruses, Ad-31 and Ad-9, revealed great adipogenic activity potential in cell cultures $(9,10)$. In humans, SMAM-1, a poultry adenovirus, and adenovirus Ad-36 have been pointed as obesity inducing agents $(11,12)$.

\section{POSSIBLE OBESITY CAUSING HUMAN AND ANIMAL VIRUSES}

\section{Human adenovirus 36 (Ad-36)}

Ad-36 was discovered in 1980, when the current world fat epidemic began $(13,4)$. It is part of a large group of 51 viral subtypes, easily transmitted through respiratory, fecal-oral and sexual pathways, as well as through contaminated personal objects.

Ad-36 presents a great affinity with fatty tissue; its DNA is found in quantities directly related to body fat. There are reports concerning the existence of obesity induced by this virus on poultry, mice and primates. Pioneer studies led by Dhurandhar and cols. $(3,14,15)$, who performed virus inoculation in these animals, revealed obesity development in $60 \%$ to $70 \%$ of the cases. It was acknowledged total body fat growth and, in larger scale, visceral fat increase, with a paradoxical decrease in serum lipid levels. The brains of Ad-36 inoculated mice were evaluated, in an attempt to find a central alteration that could produce obesity; no lesions, however, were found.

Following the poultry and mice trials, two experiments on primates were carried out by Dhurandhar and Atkinson and cols. (12). First, monkeys were inoculated through their blood streams; 18 months later, 15\% of weight gain and $25 \%$ of serum lipid levels drop were observed, thus confirming the findings of the poultry and mice studies. In the second study, monkeys were inoculated through their nasal mucosa; seven months later, all subjects presented an increase in fat tissue, with an increase of visceral fat in $66 \%$ of the cases. Drops in cholesterol level were also noticed.

In humans, available data shows that among obese people the prevalence of positive Ad-36 antibodies is larger than in regular people $(30 \%$ versus $11 \%)$. With a similar approach, in identical twins who diverge concerning their antibody status, the positive sibling presents a larger body mass index (BMI) towards the other $\left(24,5 \pm 5,2\right.$ versus $\left.23,1 \pm 4,5 \mathrm{~kg} / \mathrm{m}^{2}, \mathrm{p}<0,03\right)(12)$.

The mechanism through which Ad-36 could induce obesity has been the target of this investigation. On in vitro 3T3-Ll cell studies it seems to accelerate the preadipocyte - adipocyte differentiation rate (23). When viral gene E4orfl was inserted into 3T3-Ll cells, C/ EBP- $\beta$, PPAR $\gamma-2$ and glycerol-3-phosphate dehydrogenase were stimulated when compared to $3 \mathrm{~T} 3-\mathrm{Ll}$ controls, suggesting that the E4orfl gene is responsible for adipocyte differentiation stimulation. Vangipuram and cols. (10), also based on an in vitro study, reported the suppression of leptine mRNA expression on 3T3-1 cells in $50 \%$ of the cases after three to five days of infection, as well as an up-regulation of the enzymatic genes involved in lipogenesis, such as acetyl-CoA carboxylase- 1 and fatty acid synthase, when compared to a non infected control group, thus confirming the adipogenic role previously suggested.

If we accept Ad-36 as a cause of obesity, the next rational step would be to search for a vaccine against this infection. It would be obvious that the ideal vaccine would also contain antibodies against all possible human obesity inducing viruses. However, to identify all these species (approximately 50), we only dispose of in vitro essays and a few animal studies. Since it is well known that a few adenovirus subtypes can cause obesity in animals but not in humans (for example the Ad-37) and that the opposite is also true, the identification of antibodies for posterior vaccine elaboration becomes a laborious and, to this date, unavailable task.

Despite data suggesting viral association with obesity, it is still not possible to establish a causal relationship. Besides, adenoviruses are responsible for many kinds of infections on humans, with a high antibody positivity rate among the general population, a fact that could induce bias on studies. Ad-36 specifically, however, does not present a crossed reaction with other adenoviruses. 
Due to ethical reasons, the viral inoculation in humans is not possible. Thus, further data from animal, in vitro and in vivo studies is required so a final conclusion concerning this subject can be reached.

\section{SMAM-1}

In the early 1970's an abnormal number of chicken deaths in India was observed; aviary SMAM-1 adenovirus was deemed responsible (Ajinkya, 1985). Later on, it was known that this infection was related to a decrease in immune system function as well as to an increase on body fat in these animals.

Dhurandhar and cols. went on to inoculate chicken peritoneum with the virus; after that, he observed an increase in visceral fat that could not be justified by any dietary uptake $(18,7)$. He also noticed that birds that were not inoculated with the virus, but were kept in the same environment as the infected ones did contract the infection through their respiratory tracts and developed obesity. As in Ad-36 infections, a paradoxical decrease in serum lipid levels was observed. Also, infected animals presented with hepatic steatosis and enlarged livers.

To evaluate whether SMAM-1 could be associated with human obesity, Dhurandhar and cols. (11) analyzed blood samples from 52 obese patients in India, testing them for SMAM-1 antibodies. Only ten patients proved to be positive, but they had statistically significant larger BMI as well as lower cholesterol and triglycerides values. This was the first finding ever to raise the possibility of a virus-induced human obesity.

It remains unknown whether SMAM-1 antibodies develop as answer to viral infection or against genetically similar adenoviruses. This data contrasts with the established concept that aviary viruses could not infect humans and would not produce crossed reactions with other agents.

\section{Canine distemper vírus}

Canine distemper virus ( $C D V$ ) was the first obesity related virus, when Lyons and cols. (5) published the first report of animal viral induced obesity in rats, in 1982.

CDV is a morbilivirus that infects canines and a large number of carnivores. As with all morbiliviruses, CDV is highly contagious and the transmission occurs mainly through respiratory secretions. Infected animals present fever, systemic illness and neurologic impairment as well as immunosupression (18). Obesity can be found in up to $26 \%$ of survivors of the acute, neurologic compromising stage of the disease, and in $16 \%$ of cases in which the virus is inoculated in the peritoneum. As expected, the degree of obesity observed is comparable to those of genetic or hypothalamic origin.

The mechanism through which CDV causes obesity seems to be central nervous system (CNS) infection, with hypothalamic damage (21). The levels of circulating catecholamine are decreased, especially noradrenalin; a down regulation of hypothalamus leptine receptors and $\mathrm{MCH} \mathrm{mRNA}$ receptors can also be found (22). Griffond and cols. (21) evaluated the expression of several neurotransmission substances on acute and late infection of mice by CDV and observed that, during the acute stage of the illness, there is a dramatic drop in neuropeptide $\mathrm{Y}, \mathrm{MCH}$, hypocretin, vasopressin and tachykinin levels. During later stages of the disease, there may be a partial recovery of some of the peptides, but not all of them, thus perpetuating the pathological process. Adipogenesis will manifest as an increase in number and size of the adipocytes. Pancreatic hyperplasia is also found. These changes take place due to an imbalance in hypothalamic function as well as in its stimulation and inhibitory pathways. Up to this date, there is no evidence of relation between CDV infection and obesity on humans.

\section{Rous-associated virus type 7}

Leukocyte aviary viruses (LAV) are retroviruses that can induce neoplastic growth in a similar fashion to what is seen on B-cell lymphoma, osteopetrosis and degenerative chronic diseases, such as anemia and immunosupression (6).

Rous associated virus 7 (RAV-7) is a leukocyte aviary virus that can lead to obesity in chickens (6), which cannot be explained by a caloric increase in dietary intake and is frequently associated to low thyroid hormone levels (4). It is also associated with growth impairment, dislipidemia and hepatic fatty infiltration, whereas the thyroid and pancreas can suffer from lymphocyte infiltration. This feature can only be observed when the infection takes place during the embrionary stages of life, not being seen if the infection occurs during adulthood.

LAV can compromise large segments of the food industry. When infected chicken and egg products are being sold, the infection can reach humans. Human serum analysis has shown positivity to LAV species such as p27, p19, pl5 and p12. However, there is no evidence of human infection (24). 


\section{Borna disease vírus}

Borna disease (BD) was first described 200 years ago in Germany, as a fatal neurologic disease affecting horses and sheep. In 1939, Zwick described its etiology, linked to the Borna Virus (BDV). This virus was categorized within a new viral family, Bornaviridae (Mononegavirales order). Acute infection can lead to a non supurative encephalitis, with a tendency towards limbic, olfactory and brain stem involvement (8).

Gosztonyi and Ludwig (8) described with details the illness' pathogenesis, observing a lympho-monocytic infiltration of the hypothalamus, hippocampus, amigdala and septum, justifying the central origin of the obesity (8). Other changes can also be noticed: pancreatic hyperplasia, hypertriglyceridemia and high levels of glucose. Transmission can occur through contact with saliva, nasal and eye secretions from infected animals. Besides horses and sheep, other animals such as cats, dogs and mice can carry this virus (3).

Studies evaluating infection induced by mice inoculation observed that the animals developed obesity, behavioral changes and neurologic symptoms, some even with paralysis (25).

Human pathogenicity is still undetermined; so far, there is no evidence of relation with obesity. It is believed that this infection in humans is related to psychiatric disorders, since patients suffering from schizophrenia, obsessive-compulsive disorder and depression have presented higher prevalence of positive antibodies than the general population (26). This infection has a great response to Amantadine, a known antiviral drug.

\section{Prion}

Scrapie is a neurologic degenerative disease, known as spongiform encephalopathy. It is found among sheep, with a long incubation period. It is a slow developing disease; infected animals present behavioral disturbances, tremors, motor skill impairment and evolve invariably to death (3). The causing agent of this infection is a prion, an abnormal form of virus. On a laboratory environment, it can be transmitted through direct inoculation to mice, hamsters and monkeys. During the pre-clinical stage of the disease, there is an increase in the caloric dietary intake and weight gain; however, during the clinical course of the illness there is a progressive weight loss. Weight gain starts around the ninth week after inoculation, with its peek after 17 weeks. Furthermore, Carter and Smith (6) observed a decrease in insulin sensitivity on these animals. These au- thors also performed adrenalectomies on these subjects, noticing that this procedure had a preventive role on the metabolic disturbances, but no effect on the neurologic deterioration, as expected. The protective effect of the adrenalectomy is based on three findings: 1) scrapie induced obesity is more severe when the prion is directly inoculated into the hypothalamus; 2 ) adrenal glands' weight was larger on infected animals (due to enlarged cortex); 3 ) prion specimens found in adrenal glands of infected mice were of low virulence, suggesting that obesity in these subjects may not be related to adrenal infection.

There is no evidence of scrapie on humans, but other transmissible spongiform encephalopathies such as Creutzfeldt-Jakob and Kuru have been related.

\section{Adenovirus Ad-37}

A study led by Whigham and cols. (9) proved the relation between Ad-37 infection and obesity on chickens. There was a $111 \%$ increase in visceral fat and a $262 \%$ increase in total body fat over a period of 3,5 weeks. Similar to findings of other animal studies, caloric intake did not vary in a statistically significant way between the Ad-37 infected group and the control group. In contrast with infection by Ad-36, cholesterol levels increased and triglyceride levels diminished. Therefore, both infections caused a paradoxical drop on triglyceride levels despite the onset of obesity.

\section{Adenovirus Ad-5}

So and cols. (25) inoculated mice peritoneum with adenovirus Ad-5, demonstrating a $300 \%$ increase in total body fat, without increase in caloric intake. Serum lipid levels were not evaluated. Authors speculate that viral inflammation would be the stimulating factor to the production of PPAR- $\beta$; this substance could cause an increase in adipocyte differentiation, inducing obesity.

Since this was the first study with this adenovirus, further data is required for reaching a definitive conclusion (4).

\section{Other adenoviruses (Ad-31, Ad-9, Ad-2)}

After the demonstration of the adipogenic potential of Ad-36, other adenoviruses became the target of research. Considering this, Whigham and cols. (9) evaluated, as well as previously quoted Ad-37 (D species, Ad-36-like) and Ad-36, Ad-31 (A species), Ad-2 (C species) and Ad-9. 
The study was designed to search for answers to several questions that arose after in vivo chicken inoculation. Ad-31 and Ad-2 showed no body composition alterations; Ad-9 was not tested. In vitro metabolic analysis, with Ad-2 and Ad-31 3T3-Ll exposed cells, showed hypertriglyceridemia only in the end (again, Ad-9 was not tested) (Table 2).

\begin{tabular}{lllllll}
\hline Table 2. Possible obesity releated adenoviruses & & & \\
\hline Virus & Ad-36 & Ad-37 & Ad-31 & Ad-2 & Ad-5 \\
\hline Differentiation in 3T3-L1 cells & Yes & Yes & Yes & No & - \\
Obesity on animal models & Yes & Yes & No & No & Yes \\
Differentiation in human adipocytes & Yes & - & - & No & - \\
$\begin{array}{l}\text { Increased antibodies on obese } \\
\text { population }\end{array}$ & Yes & No & No & No & - \\
\hline
\end{tabular}

Adapted from Jhonson and Heneine (22).

Whigham also studied the interference of Ad-9 and Ad-2 infection on leptine and insulin in vitro secretion. Ad-9 presented higher lipid storage and a lower insulin secretion rate.

To test the prevalence of infections on obese patients, Atkinson and cols (12). looked for antibodies against adenoviruses Ad-37, Ad-31 and Ad-2, but found no statistically significant relation to BMI serum lipid levels.

\section{DISCUSSION}

The treatment to obesity has been one of the greatest challenges in modern medicine. It implies great lifestyle changes, sometimes even cultural ones, which becomes a frustrating subject to most professionals. A lot of hope was deposited on genetic studies, with the identification of several adipogenic genes; clinical results, however, have been unsatisfactory. These may be some of the reasons why we are now searching for new etiologic possibilities and, perhaps, even new therapeutic options.

Since the early 1980's, the role of infections on the onset and development of obesity has been questioned, with several animal studies developing in the literature. Many of these were successful in identifying and proving this causality. Up to this moment, at least eight viruses that lead to weight gain are known. Human studies are less convincing, but started to generate well founded research lines, studying not only the infectious agent, but also the entire pathologic process involved. One can observe that most adipogenic infections seem to induce obesity through a CNS lesion, except for Ad36; its DNA being identified directly within the fatty tissue, causing an increase in both adipocyte size and number. Pasarica (26), however, suggested that, in addition to Ad-36 peripheral effects, CNS disturbances could also contribute to obesity. Lower noradrenalin and cortisol levels have been found in patients tested positive to Ad-36 antibodies.

The obesity inducing mechanism, specifically in humans, the real main topic of this review, was evaluated by Vangipuram (16), realizing that glycerol-3-phosphate dehydrogenase, an adipocyte differentiation marker, was increased in 3T3-Ll and human cells infected by Ad-36. The same author (10) analyzed leptine expression and insulin sensitivity; he found that Ad-9, Ad-36 and Ad-37 suppress leptine mRNA expression. Another interesting observation was that key lipogenesis enzymes, acetylcoenzyme-A-carboxylase and fatty acid synthase, were both increased on infected mice. Furthermore, Whigham and cols. (9) evaluated adenoviruses Ad-2, Ad-31, Ad-36 and Ad-37 and confirmed that, apart from the first, all agents stimulate adipocyte differentiation.

With all the data researched in mind, one must always remember that even though our knowledge on obesity is constantly expanding, we are still far from understanding it completely. To make it possible, all fisiopathologic factors should be explored and every correlation, farfetched as it may sound, must not be undervalued.

Disclosure: No potential conflict of interest relevant to this article was reported.

\section{REFERENCES}

1. Sclafani A. Animal models of obesity: classification and characterization. Int J Obes. 1984;8(5):491-508.

2. Keith SW, Redden DT, Katzmarzyk PT, Boggiano MM, Hanlon EC, Benca RM, et al. Putative contributors to the secular increase in obesity: exploring the roads less traveled. Int $\mathrm{J}$ Obes. 2006:30(11):1585-94.

3. Dhurandhar NK. Infectobesity: obesity of infectious origin. J Nutr. 2001;131(10):2794-7.

4. Atkinson RA. Viruses as an etiology of obesity. Mayo Clin Proc. 2007;82(10):1192-8.

5. Lyons MJ, Faust IM, Hemmes RB, Buskirk DR, Hirsch J, Zabrikie JB. A virally induced obesity syndrome in mice. Science. 1982;216(4541):82-5.

6. Carter JK, Smith RE. Rapid inducion of hypothyroidism by na avian leukosis virus. Infect Immun. 1983;40(2):795-805.

7. Dhurandhar NV, Kulkarni P, Ajinkya SM, Sherikar A. Effect of adenovirus infection on adiposity inchiken. Vet Microbiol. 1992;31(23):101-7. 
8. Gosztonyi G, Ludwig H. Borna disease-neuropathology and pathogenesis. Curr Top Microbiol Immunol. 1995;190:39-73.

9. Whigham LD, Israel BA, Atkinson RL. Adipogenic potential of multiple human adenoviruses in vivo and in vitro in animals. Am J Physiol. 2006;290(1):R190-4.

10. Vangipuram SD, Yu M, Tian J, Stanhope KL, Pasarica M, Havel PJ, et al. Adipogenic human adenovirus-36 reduces leptin expression and secretion and increases glucose uptake by fat cells. Int J Obes. 2007;31(1):87-96.

11. Dhurandhar NV, Kulkarni PR, Ajiinkya SM, Sherikar AA, Atkinson RL. Association of adenovirus infection with human obesity. Obes Res. 1997;5(5):464-9

12. Atkinson RL, Dhurandhar NV, Allison DB, Bowen RL, Israel BA, Albu JB, et al. Human adenovirus- 36 is associated with increased body weight and paradoxical reduction of serum lipids. Int $\mathrm{J}$ Obes Relat Metab Disord. 2005;29(3):281-6.

13. Wigand R, Gelderblom H, Wadell G. New human adenovirus (candidate adenovirus 36 ), a novel member of subgroup D. Arch Virol. 1980;64(3):225-33.

14. Dhurandhar NV, Israel BA, Kolesar JM, Mayhew GF, Cook ME, Atkinson RL. Increased adiposity in animals due to a human vírus. Int J Obes Relat Metab Disord. 2000;24(8):989-96.

15. Dhurandhar NV, Whigham LD, Abbot DH, Schultz-Darken NJ, Israel BA, Bradley SM, et al. Human adenovirus Ad-36 promotes weight gain in male rhesus and marmoset monkeys. J Nutr. 2002;132(10):3155-60

16. Vangipuram SD, Sheele J, Atkinson RL, Holland TC, Dhurandhar NV. A human adenovirus enhances preadipocyte differentiation. Obe Res. 2004;12(5):770-7.
17. Greenway F. Virus-induced obesity [editorial]. Am J Phisiol Regul Integr Comp Physiol. 2006;290(1):188-9.

18. HarderTC, Osterhaus ADME. Canine distemper virus - a morbillivirus in search of new hosts? Trends Microbiol. 1997;5(3):120-4.

19. Bernard A, Fevre-Montange M, Bencsik A, Giraudon P, Wild TF, Confavreux $\mathrm{C}$, et al. Brain structures selectively targeted by canine distemper virus in a mouse model infection. J Neuropathol Exp Neurol. 1993;52(5):471-80.

20. Verlaeten O, Griffond B, Khuth ST, Giraudon P, Akaoba H, Belin MF, et al. Down regulation of melanin concentrating hormone in virally induced obesity. Mol Cell Endocrinol. 2001;181(1-2):207-19.

21. Griffond B, Veraleten O, Belin MF, Risold PY, Bernard A. Specific alterations of the expression of selected hypothalamic neuropeptides during acute and late mouse brain infection using a morbillivirus: relevance to the late-onset obesity? J Brain Res. 2004;1022(1-2):173-81.

22. Jhonson JA, Heneine W. Characterization of endogenous avian leukosis viruses in chicken embryonic fibroblast substrates used in prodution of measles and mumps vaccines. JVirol. 2001;75(8):3605-12.

23. Richt JA, Pfeuffer I, Christ M, Frese K, Bechter K, Herzog S. Borna disease vírus infection in animals and humans. Emerg Infect Dis. 1997;3(3):343-52.

24. Bode $\mathrm{L}$, Ludwig $\mathrm{H}$. Borna disease vírus infection, a human mental-health risk. Clin Microbiol Ver. 2003;16(3):534-45.

25. So PW, Herlihy AH, Bell JD. Adiposity induced by adenovirus 5 inoculation. Int J Obes. 2005;29(6):603-6.

26. Pasarica M, Shin AC, Yu M, Ou Yang HM, Rathod M, Jen KL, et al. Human adenovirus 36 induces adiposity, increases insulin sensitivity, and alters hypothalamic monoamines in rats. Obesity. 2006;14(11):1905-13. 